\title{
Hubungan antara Self Esteem dan Self Regulation dengan Fear of Missing Out (FOMO) Siswa SMA
}

\author{
Naya Sintiawan*, Arbin Janu Setiyowati, Ella Faridati Zen \\ Universitas Negeri Malang, Jl. Semarang No. 5 Malang, Jawa Timur, Indonesia \\ *Penulis korespondensi, Surel: nayasintia.ns@gmail.com
}

Paper received: 25-8-2021; revised: 8-9-2021; accepted: 15-9-2021

\begin{abstract}
This study aims to determine the relationship between self esteem and self regulation with fear of missing out. The research design used is descriptive correlational. The research sample amounted to 154 students obtained through purposive sampling technique. The instruments used are self esteem scale, self regulation scale and fear of missing out scale which have been tested for validity and reliability. The analysis technique used is Pearson Product Moment correlation and multiple correlation. The results showed that there was no relationship between self esteem and self regulation with fear of missing out students of SMA Negeri 7 Malang.
\end{abstract}

Keywords: self esteem; self regulation; fear of missing out

\begin{abstract}
Abstrak
Penelitian ini bertujuan untuk mengetahui hubungan antara self esteem dan self regulation dengan fear of missing out. Rancangan penelitian yang digunakan adalah deskriptif korelasional. Sampel penelitian berjumlah 154 siswa yang diperoleh melalui teknik pengambilan sampel sampling purposive. Instrumen yang digunakan adalah skala self esteem, skala self regulation dan skala fear of missing out yang telah teruji validitas dan reliabilitasnya. Teknik analisis yang digunakan korelasi Pearson Product Moment dan korelasi berganda. Hasil penelitian menunjukkan bahwa tidak terdapat hubungan antara self esteem dan self regulation dengan fear of missing out siswa SMA Negeri 7 Malang.
\end{abstract}

Kata kunci: self esteem; self regulation; fear of missing out

\section{Pendahuluan}

Teknologi Informasi dan Komunikasi berkembang begitu pesatnya, menjadikan internet sebagai alat komunikasi utama yang sangat digemari masyarakat bahkan tanpa disadari sudah menjadi bagian gaya hidup. Hal tersebut memungkinkan individu dapat berkomunikasi dengan semua orang di seluruh dunia melalui media sosial. Tim Asosiasi Penyelenggaraan Jasa Internet Indonesia (APJII) mengungkapkan hasil survei yang diambil 2019 bahwa populasi total total populasi sebanyak 171.17 juta jiwa atau sekitar $64,8 \%$ yang sudah terhubung ke internet. Diprediksi pengguna internet akan semakin meningkat dan melaju kencang sehingga pengguna internet di Indonesia diproyeksikan tahun 2023 akan mencapai 150 juta pengguna. Statistik juga menyebutkan kegiatan online yang populer di Indonesia adalah media sosial dan perpesanan seluler. Banyak masyarakat yang menjadi produsen di jejaring sosial. Produsen di jejaring sosial adalah orang-orang yang telah memproduksi sesuatu, baik tulisan di blog, foto di Instagram dan facebook, maupun mengupload video di Youtube dan Tiktok (APJII, 2020). Sekjen Asosiasi Penyelenggaraan Jasa Internet Indonesia, Soemarto (2019) juga memaparkan bahwa dari segala segmen usia, usia 15-19 tahun mempunyai penetrasi paling tinggi yakni mencapai 91\%. Dimana usia tersebut termasuk kedalam usia remaja. 
Remaja saat ini merupakan remaja milenial, dimana mereka mengenal dan dekat dengan media sosial sebagai media pencari informasi. Dengan media sosial mereka terhubung dari berbagai penjuru dunia, bahkan mengetahui keseharian teman-teman, perusahaan atau figur idola. Selain itu media sosial juga sebagai sarana berekspresi dengan beragam pilihan sehingga kebutuhan berekspresi dapat terpenuhi. Namun dibalik semua fungsi sosial tersebut, ada beberapa efek penggunaan media sosial yang mungkin dirasakan apabila menggunakannya secara berlebihan. Penggunaan media sosial yang tinggi mengidentifikasikan adanya keingintahuan pengguna terhadap keterbaruan yang ada di media sosial tersebut (up to date). Cherenson (dalam Nisa, 2020) mendapati hasil survei terhadap 333 pelajar dan mahasiswa, bahwa responden dapat menyumbangkan 11 jam sehari untuk daring pada media sosial, guna tetap terhubung dengan aktivitas yang dilakukan orang lain. Mereka akan merasa tersingkir dari teman-teman ketika tidak menggunakan media sosial (Fullerton, dalam Sianipar \& Kaloeti, 2019). Keingintahuan yang tinggi jika tidak disertai kontrol, lama kelamaan dalam penggunaannya akan menimbulkan sebuah permasalahan yang disebut fear of missing out (FoMO) yaitu perasaan takut ketinggalan aktivitas atau momen yang sedang terjadi sehingga muncul keinginan untuk selalu terhubung dengan orang lain.

Abel, dkk (2016) mendefinisikan fear of missing out sebagai perasaan tidak nyaman yang dialami individu dan terkadang semua yang dirasakan adalah perasaan tertinggal saat rekanrekannya melakukan sesuatu, mengetahui sesuatu atau memiliki sesuatu lebih baik. Perasaan takut tertinggal tersebut mendorong individu untuk terus up to date memantau kegiatan terbaru orang lain di media sosial. Individu akan merasa khawatir ketika melihat orang lain sedang melakukan aktivitas yang lebih menyenangkan daripada atau tanpa dirinya dan apabila teman-temannya memiliki pengalaman, pengetahuan dan benda kepemilikan yang lebih baik dibanding apa yang ia miliki. Abel, dkk (2016) juga menjelaskan bahwa faktor yang mempengaruhi fear of missing out adalah kecemasan dan harga diri.

Harga diri atau self esteem merupakan evaluasi seseorang dalam menilai dirinya sendiri, yakni seberapa puas seseorang dengan dirinya sendiri (Johnson, dalam Sveningson, 2012). Self esteem remaja terbentuk dari hasil evaluasi subjektif atas umpan balik yang remaja terima dari orang sekitar serta perbandingan dengan standar atau nilai kelompoknya (Santrock, 2007). Remaja pengguna media sosial yang memiliki self esteem rendah cenderung memantau media sosialnya, dikarenakan merasa khawatir tertinggal kabar terbaru sehingga tidak dianggap up to date, serta merasa khawatir hal yang ia posting di media sosial mendapatkan respon negatif sehingga ingin segera menghapusnya (Prawesti \& Dewi, 2016). Brandon (dalam Retnaningrum 2019) memaparkan bahwa individu dengan self esteem rendah menggunakan media sosial untuk mencari pengagum dan penilaian positif dari orang lain yang tidak didapatkan di dunia nyata. Dalam penggunaan media sosial tersebut, individu juga mengalami proses penilaian diri melalui proses membandingkan diri dengan orang lain. Hal ini dijelaskan sebagai teori perbandingan sosial oleh Festinger, (dalam Abel, dkk. 2016) yang menentukan nilai pribadi melalui proses membandingkan diri atas orang lain.

Dampak dari fear of missing out dapat membuat individu mudah frustasi karena kurang bersyukur terhadap dirinya dengan terus membandingkan diri dengan orang lain, sulit menerima diri dan ekspektasi yang berlebihan. Individu yang terkena fear of missing out menjadi seseorang yang sering melupakan kenyataan hidupnya yang sebenarnya. Karena sibuk up to date untuk mengukuhkan eksistensi dan pencitraan di dunia maya, hingga mereka rela mengabaikan aktivitas-aktivitas di kehidupan nyata. Hal tersebut membuat individu 
memerlukan kemampuan menyusun strategi dalam menghadapi dan menghindari stimulus yang dapat menghambat aktivitas sehari-hari. Kemampuan untuk menyusun strategi dalam menetapkan perilaku secara terus-menerus dalam upaya mencapai tujuan yang diinginkan ini disebut regulasi diri (Bandura dkk, dalam Ormrod, 2012). Wahjoni, dkk (2015) memaparkan bahwa individu yang memiliki regulasi diri yang tinggi mampu mengendalikan penggunaan media sosial mereka sehingga akan terhindar dari efek-efek negatif seperti keterikatan pada media sosial hingga pemakaian yang kompulsif dan adiktif. Pemakain gadget yang didasari oleh media sosial yang kompulsif merupakan salah satu komponen yang dapat membangun fear of missing out (Reagle, 2015).

Hasil penelitian yang dilakukan oleh Retnaningrum (2019) mengenai hubungan self esteem dengan fear of missing out menunjukkan bahwa bahwa terdapat hubungan negatif signifikan antara self esteem dengan fear of missing out. Hal tersebut menunjukkan bahwa semakin tinggi tingkat self esteem maka semakin rendah tingkat fear of missing out pada individu. Sianipar \& Kaloeti (2019) dalam penelitiannya menunjukkan bahwa terdapat hubungan yang negatif signifikan antara self regulation dengan fear of missing out. Hal tersebut menunjukkan bahwa semakin tinggi regulasi diri pada individu maka semakin rendah tingkat fear of missing out pada individu.

Penelitian ini bertujuan untuk: (1) mengetahui adanya hubungan antara self esteem dengan fear of missing out pada siswa SMA Negeri 7 Malang, (2) mengetahui adanya hubungan antara self regulation dengan fear of missing out pada siswa SMA Negeri 7 Malang, dan (3) mengetahui adanya hubungan antara self esteem dan self regulation dengan fear of missing out pada siswa SMA Negeri 7 Malang. Hasil penelitian ini dapat digunakan oleh guru BK/konselor di sekolah untuk mengetahui profil self esteem, self regulation dan fear of missing out siswa, sehingga dapat dirancang layanan bimbingan dan konseling yang relevan dengan temuan penelitian tersebut.

\section{Metode}

Penelitian ini menggunakan pendekatan kuantitatif dengan rancangan korelasional. Populasi penelitian ini yaitu siswa kelas 10 dan kelas 11 SMA Negeri Malang sejumlah 688 siswa. Pengambilan sampel menggunakan nonprobability sampling dengan teknik sampling purposive dimana peneliti memilah-milah sampel yang sesuai dengan kriteria yang telah ditentukan. Kriteria sampel pada penelitian ini yaitu berjenis kelamin laki-laki dan perempuan, siswa kelas 10 dan 11, serta memiliki dan aktif menggunakan media sosial. Penentuan jumlah sampel diambil 15\% dari jumlah populasi setiap tingkatan kelasnya, dengan total sampel 154 siswa yang terdiri dari 78 siswa kelas 10 dan 76 siswa kelas 11.

Data dalam penelitian ini diambil menggunakan skala sebagai instrumennya. Instrumen yang digunakan untuk mengukur variabel menggunakan model skala likert. Ada tiga skala yang digunakan yaitu: skala self esteem, skala self regulation, dan skala fear of missing out. Skala self esteem dikembangkan menggunakan teori Coopersmith (dalam Febrita, 2017) yang memiliki empat aspek yaitu kekuatan (power), keberartian (significance), kebajikan (virtue) dan kemampuan (competence). Skala self esteem terdiri 68 item, setelah dilakukan uji validitas didapatkan hasil sebanyak 45 item yang valid dan memiliki koefisien reliabilitas sebesar 0.925 .

Skala self regulation dikembangkan menggunakan teori Bandura, Schunk dan Zimmerman (dalam Ormrod, 2011) yang memiliki lima aspek yaitu mengatur standar dan tujuan (setting standards and goals), observasi diri (self observation), evaluasi diri (self 
evaluation), reaksi diri (self reaction), dan refleksi diri (self reflection). Skala self regulation terdiri dari 69 item, setelah dilakukan uji validitas didapatkan hasil sebanyak 49 item yang valid dan memiliki koefisien reliabilitas sebesar 0.951 .

Skala fear of missing out dikembangkan menggunakan teori Przybylski, dkk (2013) yang memiliki tiga aspek yaitu tidak terpenuhinya kebutuhan psikologis akan relatedness, competence, dan autonomy. Skala fear of missing out terdiri 67 item, setelah dilakukan uji validitas didapatkan hasil sebanyak 50 item yang valid dan memiliki koefisien reliabilitas sebesar 0.949 .

Pengumpulan data dilakukan dengan menggunakan Google Form. Data yang terkumpul dianalisis dengan untuk menjawab rumusan masalah atau menguji hipotesis penelitian. Penelitian ini menggunakan analisis deskriptif dan analisis korelasional. Teknik analisis yang digunakan yaitu korelasi Pearson Product Moment dan korelasi berganda yang sebelumnya terlebih dahulu diuji normalitas dan linieritasnya. Untuk memudahkan proses perhitungan, digunakan program Statistical Package for Social Science (SPSS) for windows 2.8 Version.

\section{Hasil dan Pembahasan}

\subsection{Hasil}

\subsubsection{Hasil Analisis Deskriptif}

Peneliti mendeskripsikan tingkat self esteem, self regulation dan fear of missing out dengan tiga kategori yaitu tinggi, sedang, dan rendah. Berikut ini adalah uraian kategorisasi tingkat self esteem, self regulation dan fear of missing out siswa SMA Negeri 7 Malang:

Tabel 1. Kategorisasi Tingkat Self Esteem, Self Regulation dan Fear of Missing Out

\begin{tabular}{lcccccc}
\hline \multirow{2}{*}{ Kategorisasi } & \multicolumn{2}{c}{ Self Esteem } & \multicolumn{2}{c}{ Self Regulation } & \multicolumn{2}{c}{ FoMO } \\
\cline { 2 - 7 } & Frekuensi & Persentase & Frekuensi & Persentase & Frekuensi & Persentase \\
\hline Rendah & 23 & $14.9 \%$ & 26 & $16.9 \%$ & 20 & $13 \%$ \\
Sedang & 100 & $64.9 \%$ & 103 & $66.9 \%$ & 111 & $72.1 \%$ \\
Tinggi & 31 & $20.1 \%$ & 25 & $16.2 \%$ & 23 & $14.9 \%$ \\
\hline
\end{tabular}

Berdasarkan tabel 1, dapat diketahui bahwa sebagaian siswa SMA Negeri 7 Malang memiliki tingkat self esteem, self regulation dan fear of missing out yang sedang.

\subsubsection{Hasil Pengujian Persyaratan Analisis}

Hasil uji normalitas menunjukkan bahwa variabel self esteem (X1) dengan fear of missing out (Y) memiliki nilai signifikansi 0,200>0,05 dan variabel self regulation (X2) dengan fear of missing out (Y) memiliki nilai signifikansi $0,200>0,05$. Berdasarkan data nilai signifikansi tersebut maka dapat disimpulkan bahwa data berdistribusi normal.

Hasil uji linieritas menunjukkan bahwa variabel self esteem (X1) dengan fear of missing out (Y) memiliki nilai sig. devian of linearity $0,173>0,05$ dan variabel selfregulation (X2) dengan fear of missing out $(\mathrm{Y})$ memiliki nilai sig. devian of linearity $0,869>0,05$. Berdasarkan data nilai sig. deviation of linearity tersebut maka dapat disimpulkan bahwa data berhubungan secara linieritas. 


\subsubsection{Hasil Pengujian Hipotesis}

\subsubsection{Hasil Pengujian Hipotesis Hubungan antara Self Esteem dengan Fear of Missing Out}

Hasil analisis menunjukkan bahwa $\mathrm{r}_{\text {hitung }}=0,69<\mathrm{r}_{\text {tabel }}=0,156$ dan nilai sig. $0,395>0,05$, maka menunjukkan bahwa $\mathrm{H}_{0}$ diterima dan $\mathrm{H}_{1}$ ditolak. Artinya, self esteem (X1) tidak terdapat hubungan signifikan dengan fear of missing out (Y) pada siswa SMA Negeri 7 Malang.

\subsubsection{Hasil Pengujian Hipotesis Hubungan antara Self Regulation dengan Fear of Missing Out}

Hasil analisis menunjukkan bahwa $r_{\text {hitung }}=0,16>r_{\text {tabel }}=0,156$ dan nilai sig. $0,047<0,05$, maka menunjukkan bahwa $\mathrm{H}_{0}$ ditolak dan $\mathrm{H}_{1}$ diterima. Artinya, self regulation (X2) terdapat hubungan positif signifikan dengan fear of missing out (Y) pada siswa SMA Negeri 7 Malang.

\subsubsection{Hasil Pengujian Hipotesis Hubungan antara Self Esteem dan Self Regulation dengan Fear of Missing Out}

Berdasarkan pengujian, hasil analisis korelasi berganda menunjukkan bahwa diketahui nilai sig. $F$ Change $=0,96>0,05$, maka menunjukkan bahwa $\mathrm{H}_{0}$ diterima dan $\mathrm{H}_{1}$ ditolak. Artinya tidak terdapat hubungan signifikan secara simultan antara variabel self esteem (X1) dan self regulation (X2) dengan fear of missing out $(\mathrm{Y})$.

\subsection{Pembahasan}

\subsection{Hubungan Antara Self Esteem dengan Fear of Missing Out (FoMO) pada Siswa SMA Negeri 7 Malang}

Berdasarkan hasil analisis dapat diketahui bahwa hipotesis penelitian ditolak, yaitu tidak ada korelasi antara self esteem dengan fear of missing out pada siswa SMA Negeri 7 Malang. Ditolaknya hipotesis penelitian tersebut, menunjukkan bahwa self esteem dianggap tidak menjadi salah satu faktor yang mempengaruhi terbentuknya fear of missing out siswa SMA Negeri 7 Malang. Tinggi atau rendahnya tingkat self esteem yang dimiliki siswa tidak mempengaruhi tinggi atau rendahnya tingkat fear of missing out pada siswa. Hal ini diperkuat oleh data deskriptif yang menunjukkan sebagian besar siswa yang menjadi subjek penelitian memiliki tingkat self esteem pada kategori sedang, hal ini menandakan bahwa sebagian besar subjek mempunyai penilaian yang cukup positif terhadap diri sendiri, namun data tingkat fear of missing out siswa sebagian besar juga berada pada kategori sedang, yang menunjukkan bahwa siswa cukup merasa takut tertinggal dan ingin selalu terhubung dengan orang lain. Serupa dengan penelitian Siddik, dkk (2020) yang menjelaskan bahwa kontribusi self esteem dengan fear of missing out tergolong rendah yaitu $11,3 \%$. Alasan siswa untuk terus terhubung dengan orang lain melalui media sosial bukan karena untuk meningkatkan self esteem nya, namun didorong kebutuhan memperoleh informasi dalam menambah ilmu pengetahuan dan kebutuhan untuk pendidikan dengan persentase $85 \%$ dari subjek total.

Temuan penelitian yang menunjukkan tidak adanya korelasi antara self esteem dengan fear of missing out dapat dianalisis dari sisi karakteristik subjek penelitian yaitu siswa SMA yang termasuk generasi Z. Gen Z yang berusia 14-25 tahun ini memiliki kecenderungan lebih 
untuk memilih situs media sosial untuk berkomunikasi dan berinteraksi dengan orang-orang yang mereka kenal daripada generasi lain dan merasa penting untuk memberikan umpan balik dan komentar aktif tentang segala sesuatu yang mereka gunakan, selain itu mereka juga menghargai pendapat yang diberikan oleh orang lain (eMarketer, 2011). Artinya kebutuhan untuk terlibat dan diinformasikan kepada/dengan orang lain adalah alasan utama dibalik penggunaan media sosial oleh Gen Z. Pendapat tersebut menunjukkan bahwa fear of missing out merupakan kondisi yang wajar dihadapi generasi $\mathrm{Z}$ dan tidak berkaitan dengan tinggi rendahnya self esteem.

\subsection{Hubungan Antara Self Regulation dengan Fear of Missing Out (FoMO) pada Siswa SMA Negeri 7 Malang}

Berdasarkan hasil analisis dapat diketahui bahwa hipotesis penelitian diterima, yaitu terdapat korelasi positif signifikan antara self regulation dengan fear of missing out pada siswa SMA Negeri 7 Malang. Hal ini dapat diartikan bahwa semakin tinggi tingkat self regulation, semakin tinggi pula tingkat fear of missing out pada siswa SMA Negeri 7 Malang. Begitupun sebaliknya, semakin rendah tingkat self regulation siswa, semakin rendah pula tingkat fear of missing out. Berdasarkan hasil wawancara peneliti kepada siswa SMA Negeri 7 Malang yang menjadi subjek dalam penelitian ini, didapatkan bahwa media sosial pada masa pandemi Covid-19 menjadi platform utama bagi siswa untuk meraih informasi terutama sumber rujukan belajar dan media pengembangan bakat dan minat.

Temuan penelitian yang menunjukkan semakin tinggi tingkat self regulation, semakin tinggi pula tingkat fear of missing out siswa dapat dimaknai dari perspektif dari sisi penerapan sistem pembelajaran daring selama masa pandemi ini. Sistem pembelajaran daring banyak memanfaatkan aplikasi media sosial agar memudahkan siswa tetap terhubung dengan pembelajaran. Pemanfaatan media sosial untuk pembelajaran ini mengakibatkan kebutuhan siswa untuk terus terhubung dengan media sosial akan semakin meningkat. Perasaan takut tertinggal informasi media sosial yang dialami oleh siswa ditandai dengan perilaku yang ingin terus uptodate konten-konten yang bersikap positif misalnya konten instagram tips menghitung cepat, konten tiktok tentang tips belajar mudah corel draw / photoshop, konten vlog youtube publik figur tentang berbagi pengalaman kesuksesan dan lain sebagainya. Adanya kebutuhan untuk terus terhubung dengan media sosial ini menjadi hal yang wajar dan diperlukan kemampuan regulasi diri yang memadai untuk dapat memfilter pemanfaatan media sosial secara positif khususnya yang berkaitan dengan kebutuhan pembelajaran daring.

Perasaan takut tertinggal informasi di media sosial yang didasari keinginan mengembangkan pengetahuan secara mandiri juga dibutuhkan usaha pengendalian perilaku atau yang disebut regulasi diri agar dapat mencapai tujuan kesuksesan yang telah ditetapkan sebelumnya. Hasil analisis yang menunjukkan adanya korelasi positif signifikan antara dua variabel ini memiliki tingkat hubungan yang sangat rendah dan kontribusinya (Rsquare) sangatlah kecil yaitu sebesar 2,6\%. Hal ini disebabkan siswa yang memiliki self regulation yang tinggi, kemungkinan besar dapat terhindar dari tingkat fear of missing out yang tinggi. Hal tersebut sejalan dengan penelitian Wanjohi, dkk (2013), yaitu individu yang memiliki self regulation yang tinggi akan dapat mengendalikan penggunaan media sosial dan akan terhindar dari efek-efek negatif seperti keterikatan pada media sosial yang kompulsif dan adiktif. 


\subsection{Hubungan Antara Self Esteem dan Self Regulation dengan Fear of Missing Out (FoMO) pada Siswa SMA Negeri 7 Malang}

Berdasarkan hasil analisis dapat diketahui bahwa hipotesis penelitian ditolak, yaitu tidak terdapat korelasi antara self esteem dan self regulation dengan fear of missing out pada siswa SMA Negeri 7 Malang. Temuan penelitian ini menunjukkan bahwa keterhubungan siswa SMA dengan media social tidak bisa diasosiasikan dengan tinggi rendahnya self esteem dan self regulation. Hal ini terjadi karena dalam konteks kehidupan siswa SMA dimana mereka merupakan bagian dari generasi Z, teknologi khususnya pemanfaatan media social adalah bagian dari dunia mereka. Selain itu kebijakan sistem pembelajaran daring selama masa pandemi, memberikan kontribusi terhadap meningkatnya fear of missing out siswa khususnya pemanfaatan media sosial sebagai sarana pembelajaran.

Remaja yang mampu melakukan penilaian diri secara positif dapat lebih menghargai dirinya dan hal tersebut dapat berfungsi dengan baik dalam hubungan sosialnya. Sebaliknya, remaja yang melakukan penilaian diri secara negatif akan merasa dikucilkan, terasing dan tidak diperhatikan sehingga mengalami gangguan dalam hubungan sosialnya (Tafarodi \& Swann, 2001). Sedangkan remaja yang mampu melakukan pengendalian diri yang baik dapat mengatur perilakunya untuk mencapai tujuan yang telah yang telah ditetapkan (Zimmerman, dalam Ormrod, 2003). Dalam hal ini, baik remaja yang memiliki penilaian diri yang positif maupun negatif serta pengendalian diri yang tinggi maupun rendah tidak menutup kemungkinan bahwa remaja dapat mengalami fear of missing out. Hal ini dikarenakan self esteem dan self regulation secara simultan tidak memberi kontribusi terhadap terbentuknya fear of missing out pada siswa. Remaja yang memiliki penilaian diri baik positif maupun negatif dan pengendalian diri yang tinggi maupun rendah, akan tetap menjaga koneksi sosial dan terus terhubung dengan orang lain melalui media sosial, bukan karena merasa ketakutan akan ketinggalan ketinggalan aktivitas atau momen yang sedang terjadi di kehidupan sosialnya namun untuk kebutuhan pencapaian tujuan tertentu yang telah ditetapkan seperti halnya kebutuhan dalam hubungan sosial, kebutuhan informasi, hiburan, serta menghabiskan waktu luang. Hal ini selaras dengan penelitian yang dilakukan oleh Siddik, dkk (2020) yaitu remaja yang mengalami fear of missing out tidak hanya menggunakan media sosial untuk menjaga koneksi sosial dengan orang lain, namun juga karena alasan-alasan lain seperti untuk pemenuhan kebutuhan informasi, hiburan, dan menghabiskan waktu luang.

Penelitian ini tidak menspesifikkan studi pada penggunaan jenis media sosial tertentu, memberikan kontribusi terhadap temuan hasil penelitian yang menunjukkan tidak adanya hubungan antara self esteem dan self regulation dengan fear of missing out. Artinya diperlukan studi lebih lanjut untuk mengidentifikasi jenis media sosial yang patut banyak memberikan kontribusi terhadap tingkat fear of missing out siswa. Upaya menspesifikkan jenis media sosial ini diperlukan untuk dapat dilakukan analisis lebih lanjut hubungan antara self esteem dan self regulation dengan fear missing out siswa SMA.

\section{Simpulan}

Berdasarkan hasil penelitian dapat ditarik simpulan bahwa: (1) tidak terdapat hubungan antara self esteem dengan fear of missing out pada siswa SMA Negeri 7 Malang. Artinya, bahwa self esteem dianggap tidak menjadi salah satu faktor yang mempengaruhi terbentuknya fear of missing out siswa, (2) terdapat hubungan positif signifikan antara self regulation dengan fear of missing out pada siswa SMA Negeri 7 Malang. Artinya, bahwa semakin 
tinggi tingkat self regulation, semakin tinggi pula tingkat fear of missing out pada siswa, begitu sebaliknya, (3) tidak terdapat korelasi antara self esteem dan self regulation dengan fear of missing out pada siswa SMA Negeri 7 Malang. Artinya, self esteem dan self regulation secara simultan tidak memberi kontribusi terhadap terbentuknya fear of missing out pada siswa.

\section{Daftar Rujukan}

Asosiasi Penyelenggara Jasa Internet Indonesia. (2020). Survei Internet APJII 2017. Dari situs: https://apjii.or.id/survei2020.

Abel, J. P., Buff, C. L., \& Burr, S. A. (2016). Social Media and the Fear of Missing Out: Scale Development and Assessment. Journal of Business \& Economics Research (JBER), 14(1), 33-44. https://doi.org/10.19030/jber.v14i1.9554

eMarketer. (2021) Social Media Outlook for 2011. Available from: www. emarketer.com

Febrita, S. S. (2017). Self Esteem Remaja Pada Keluarga Broken Home. Universitas Mercu Buana, Yogyakarta, Indonesia.

Nisa. (2015). Peran Fear of Missing Out (FoMO) Terhadap Atensi Mahasiswa Fakultas Psikologi Universitas Sumatera Utara dalam Proses Belajar. Universitas Sumatera Utara, Medan, Indonesia.

Omrod, J. E. (2003). Educational Psychology (Ed). New Jersey: Pearson Education.

Ormrod, J.E. (2011). Human Learning Edisi Keenam. New York: Pearson.

Ormrod, J. E. (2012). Human Learning Sixth Edition. United States: Pearson Education.

Prawesti, F. S., \& Dewi, D. K. (2016). Self Esteem dan Self Disclosure Pada Mahasiswa Psikologi Pengguna Blackberry Messenger. Jurnal Psikologi Teori Dan Terapan, 7(1), 1. https://doi.org/10.26740/jptt.v7n1.p1-8

Przybylski, A. K., Murayama, K., Dehaan, C. R., \& Gladwell, V. (2013). Motivational, Emotional, And Behavioral Correlates Of Fear of Missing Out. Computers in Human Behavior, 29(4), 1841-1848. https://doi.org/10.1016/j.chb.2013.02.014

Reagle, J. (2015). Following The Joneses: FOMO And Conspicuos Sociality. Peer-Reviewed Journal on The Internet, 20(10). https://doi.org/10.5210/fm.v20i10.6064

Retnaningrum, Y.D. (2019). Hubungan Antara Self Esteem Dengan FOMO Pada Mahasiswa Universitas Mercu Buana Yogyakarta. Universitas Mercu Buana, Yogyakarta, Indonesia.

Santrock, J.W. (2007). Remaja Edisi Kesebelas (Jilid 1). New York: Erlangga.

Sianipar, N. A., \& Kaloeti, D. V. S. (2019). Hubungan Antara Regulasi Diri Dengan Fear Of Missing Out (FOMO) Pada Mahasiswa Tahun Pertama. Jurnal Empati, 8(1), 136-143.

Siddik, S., Mafaza, M., \& Sembiring, L. S. (2020). Peran Harga Diri terhadap Fear of Missing Out pada Remaja Pengguna Situs Jejaring Sosial. Jurnal Psikologi Teori dan Terapan, 10(2), 127. https://doi.org/10.26740/jptt.v10n2.p127-138

Sveningsson, E. (2012). The relation between peer social status and self-esteem in middle childhood. http://lup.lub.lu.se/luur/download?func=downloadFile\&recordOId=3437755\&fileOId=3437767

Tafarodi, R. W., \& Swann, W. B. (2001). Two-dimensional self-esteem: theory and measurement. Personality and Individual Differences, 31(5), 653-673. https://doi.org/10.1016/S0191- 8869(00)00169-0

Wanjohi, R.N., Mwebi, R.B. \& Nyang'ara, N. M. (2015). Self-Regulation Of Facebook Usage And Academic Perfomance Of Student In Kenyan Universities. Journal of Education and Practice, 6(14), 109-114. 